\title{
Diet, size and reproductive biology of the silver catfish, Chrysichthys nigrodigitatus (Siluformes: Bagridae) in the Cross River, Nigeria
}

\author{
Benedict Obeten Offem ${ }^{1}$, Yemi Akegbejo-Samsons ${ }^{2} \&$ Isaac Tunde Omoniyi² \\ 1. Department of Fisheries, Faculty of Agriculture and Forestry, Obubra Campus, Cross River State, Nigeria, Phone 234 \\ (0) 805593 0219; benbeff06@yahoo.com \\ 2. Department of Aquaculture and Fisheries, College of Environmental Resource Management, University of Agriculture, \\ Abeokuta, Nigeria
}

Received 01-II-2008. C Corrected 22-V-2008. Accepted 31-VII-2008.

\begin{abstract}
The silver catfish, Chrysichthys nigrodigitatus (Lacépède: 1803) is a highly valued food-fish included among the dominant commercial catches exploited in major rivers of Africa. To provide useful biological data for management, samples were collected monthly between January (2005) and December (2007) in three zones: I: Upper Cross River (grassland), II: Middle Cross River (mixed forest and grassland), and III: Lower Cross River (rainforest)] along $200 \mathrm{~km}$ length of the Cross River, Nigeria. Data from 1248 specimens were processed using: allometric coefficient (b), gonado-somatic index, Fulton's condition factor and diversity indices. Male dominance was observed in all populations; C. nigrodigitatus reached maturity at $11.5 \mathrm{~cm}$ (male) and $16.7 \mathrm{~cm}$ (female) total length. Gonado-somatic index was higher for females with a peak in the early rains. The breeding period was between April and August with mean fecundity ranging between $4522 \pm 1924$ eggs and $20321 \pm 5543$ eggs. This was directly related to total length and weight by the regression models: $\mathrm{F}=2365.88+560.22 \log \mathrm{L}$ and $\mathrm{F}=5025.81+56.34 \log \mathrm{W}$ respectively. Exponential equations for length-weight relationships were $\mathrm{Wt}=-$ $1.997 \mathrm{Lt}^{2.206}$ (Zone I), $\mathrm{W}=-2.831 \mathrm{Lt}^{3.040}$ (Zone II) and $\mathrm{Wt}=-2.245 \mathrm{Lt}^{2.995}$ (Zone III). The mean allometric coefficient (b) showed significant departure from cubic value (negative allometry) for Zone I while Zones II and III showed no difference, indicating isometry. Dominant items in the diet were fish and fish parts constituting $21.6 \%$ with Food Richness and Gut Repletion Index of 18 and 100\% respectively, in all zones. Diet Breadth of 0.802 (Zone I), 0.922 (Zone II) and 0.910 (Zone III) indicate a high trophic flexibility that enables switching from one diet to another according to availability. Mean condition factor for males varied from $0.718 \pm 0.117$ minimum in Zone I to $0.996 \pm 0.062$ maximum in Zone III. Forest inland wetlands (Zone II and III) of Cross River provided better condition for C. nigrodigitatus. Rev. Biol. Trop. 56 (4): 1785-1799. Epub 2008 December 12.
\end{abstract}

Key words: Assessment, river, reproduction, length- weight, condition factor, diet habit, bagridae.

The silver catfish, Chrysichthys nigrodigitatus (Lacépède) occurs in most of the major rivers in Africa including Nigeria, Senegal, Gambia, Ivory Coast, Liberia, Zaire, and Gabon (Ezenwa 1981). They are highly valued food-fish in these native African waters and are among the dominant fishes of commercial catches. Knowledge on their biology is important for management and sustainable utilization of stock. For this reason biological assessment had been carried out by many authors including; Ezenwa (1982) and Ekanem (1992) to determine the quality of pop- ulations of the species in different water bodies in Nigeria. The fish is caught with drag net, hook and line, bottom-set gillnet and bottom-set traps because of the bottom dwelling habit. There is acute reduction in population of this species in Nigeria because of the over-exploitative nature of indigenous fishers that destroy the habitats of this species. Effort has being geared towards the conservation of these species through fisheries regulation.

The dearth of published information on the biology of this species in the South-East and 
Niger-Delta area of Nigeria has been reported by Teugels et al 1992. This paper presents a study of the diet habit, sex composition, reproductive characteristics and condition factor of $C$. nigrodigitatus in the three distinguished habitats of Cross River. The study is aimed at providing information on the structure and quality of the population of the fish species for proper management and conservation in the three habitats of the study area.

\section{MATERIALS AND METHODS}

Study site: The study was conducted along the $200 \mathrm{~km}$ length of Cross River located at the South - Eastern part of Nigeria $\left(4^{\circ} .25^{\prime}\right.$ $\left.-7^{\circ} 00^{\prime} \mathrm{N} ; 7^{\circ} .15^{\prime}-9^{\circ} .30^{\prime} \mathrm{E}\right)$. The climate is largely tropical- humid with dry (November February) and wet (April - October) seasons.

Data collection: 1248 samples (779 males and 469 females) were randomly taken from artisanal catch in three zones of the study area. These were, $\mathrm{I}=$ Upper reach (savanna grassland), II = Middle reach (forest-savanna) and III = Lower reach (rainforest). Each zone had three randomly selected sampling stations. The fish were caught predominantly with gillnet $(22-76 \mathrm{~mm}$ stretched mesh size) and analyzed monthly (once every month from $6.00 \mathrm{am}$ to $11.00 \mathrm{am}$ ) between January 2005 and January 2007. Fish samples were identified using Olaosebikan and Raji (1988) and FAO Species Identification Sheet (Fisher and Bianchi 1984). Samples were mopped and cleaned with filter papers and weighed to the nearest $0.1 \mathrm{~g}$ with balance (Loading Mettler Model PM 2000 for small species and Salter Model 180 for larger species). All samples were then fixed in $10 \%$ formalin and later preserved in $70 \%$ ethanol and deposited in the Fisheries Museum (Catalogue No.: CRUTECH 1089) at the Fisheries Department of Cross River University, Obubra campus, Nigeria. Sex ratio of the fish was computed using Chi-squre test $\left(\mathrm{x}^{2}\right)$, following the equation of Fisher, (1970) assuming that the ratio of male to female in the population was 1: 1 .
Ripe female fish (294) were used for fecundity estimation.

Fecundity was estimated by gravimetric method (Largler 1978) using sub-samples collected from the anterior, posterior or middle of the ovaries. Fecundity - length, fecundityweight and fecundity-condition index relationships were determined using the expression by King (1991).

$$
\mathrm{F}=\mathrm{ax} \mathrm{x}^{\mathrm{b}}
$$

$\mathrm{F}=$ dependable variable (absolute fecundity), $\mathrm{x}=$ independent variables (body weight, total Length, standard length and condition index) $\mathrm{a}=$ constant, $\mathrm{b}=$ regression coefficient both of which were evaluated by least squares regression analysis using log transformed data based on the formula:

$$
\log F=\log a+b \log x i
$$

Mean relative fecundity was calculated as number of eggs per unit length or per unit weight. The length at first maturity was worked out by plotting the percentage of mature fish against their length. The length at which $50 \%$ of the females were mature (with developed ova in their ovaries) was considered as length at first maturity.

Gonad cycle was determined from changes in gonad weight, as shown by Gonado-somatic Index (GDI) calculated for both sexes by expressing the gonad weight as percentage of body weight (June 1953). Egg diameter was measured from samples collected from different parts of the ovary (anterior, middle and posterior parts). The gonad maturity stages were assigned according to Vazzoler (1996) as: immature, initial maturity, final maturity, ripe, spent and recovering- spent.

Length-weight relationship of fish was estimated from the equation $\mathrm{W}=\mathrm{aL}^{\mathrm{b}}$ (Pauly 1984). $\mathrm{W}=$ weight of fish in grams, $\mathrm{L}=$ total length of fish in centimeters, "a" is proportionality constant and " $b$ " is the allometric coefficient both estimated by method of least squares (Lagler 1956) using logarithmically 
transformed expression; $\log \mathrm{W}=\operatorname{lag} \mathrm{a}+\mathrm{b} \log$ L. To investigate whether the species followed cube law the values of the exponent " $b$ " was tested against ' 3 ' applying Student's t test. An ANOVA was used to determine if there were significant differences in the LWR between the sexes. Fulton's condition factor (CF) was determined using the expression by Ricker (1975) as

$$
\mathrm{K}=\frac{\mathrm{W} 100}{\mathrm{~L}^{3}}
$$

$\mathrm{K}=$ condition factor, $\mathrm{W}=$ total weight $(\mathrm{g})$ and $\mathrm{L}$ $=$ total length $(\mathrm{cm})$.

Specimen for diet studies was dissected and their guts removed immediately after capture and stored in formaldehyde solution (4\%) until the contents were analysed. Gut analysis was later carried out with the food items identified to the lowest possible taxon and analyzed quantitatively for percentage composition by number $(\mathrm{N})$ and frequency of occurrence (FO), according to Borutsky et al (1961). In calculation unidentified food items were not used. Diet similarity among seasons and zones was investigated using Schoener Overlap Index (Schoener, 1970) (C);

$$
\text { Cxy }=1-0.5 \sum \text { (pxi - pyi). }
$$

where pxi and pyi are the proportions by number of food type $\mathrm{i}$ in the diet of groups $\mathrm{x}$ and $\mathrm{y}$ (seasons and zones), respectively. If the $\mathrm{C}$ value is bigger than 0.8 , it means that the diet of the two groups is similar. The extent of the diet (diet breath) was calculated using the diversity index of Shanon- Wienner $(\mathrm{H})$;

$$
\mathrm{H}^{\prime}=-\sum \mathrm{pi} \cdot \log _{2} \mathrm{pi}
$$

where pi is the proportion by the number of food type i. This Index has the sensitivity for detecting changes in species diversity and provides a general indication of the relative magnitude of trophic specialization (Berg 1979). Other biological indices including Food Richness; expressed using Margalef's index: calculates the number of food items relative to the individual in the sample:

$$
\mathrm{d}=(\mathrm{S}-1) / \log \mathrm{N})
$$

where $\mathrm{d}=$ Margalef's index, $\mathrm{S}$ is the number of species and $\mathrm{N}$ is the number of individuals and Gut Repletion Index (\% of non-empty stomach) (GRI) were also estimated for samples from each zone according to Hyslop (1980). The index of relative importance (IRI) of Pinkas et al (1971) was used to determine the importance of each food type.

\section{RESULT}

Reproductive biology: Male dominance was observed in the species, as male: female sex ratio (1: 0.5$)$ of $C$. nigrodigitatus over the entire study period showed highly significant (Chi-square, $\mathrm{P}<0.001$ ) monthly variation from the expected sex ratio of $1: 1$ with males more numerous in all months of sampling except September 2005 and December 2007 (Table 1).

Maturity curve (Figure 1) plotted for the fish by direct observation of ovaries and testis and changes in the proportion of mature fish in the population with increasing fish length showed that $50 \%$ of the males matured at $11.5 \mathrm{~cm}$ (size at first maturity for male) total length (TL) and females at length $16.7 \mathrm{~cm}$ (size at first maturity for female).

Highest proportion of gonadal ripe stages (VI) occurred in April and May while fish in spent condition (VII) increased from September to January then decreased progressively to April (Figure 2). $62.3 \%$ of female and $79 \%$ of male fish were observed to be undergoing reproductive processes during study period (Table 2).

GSI varied from 1.25 to 7.91 with a mean index of $4.78 \pm 3.21$ in female fish and from 0.57 to 3.17 with a mean index of $2.89 \pm 1.41$ in male fish. GSI values were higher in the wet season $(\mathrm{p}<0.05)$.

The GSI changes in $C$. nigrodigitatus females and males in consecutive months are presented in Figure 3. Both the values were 


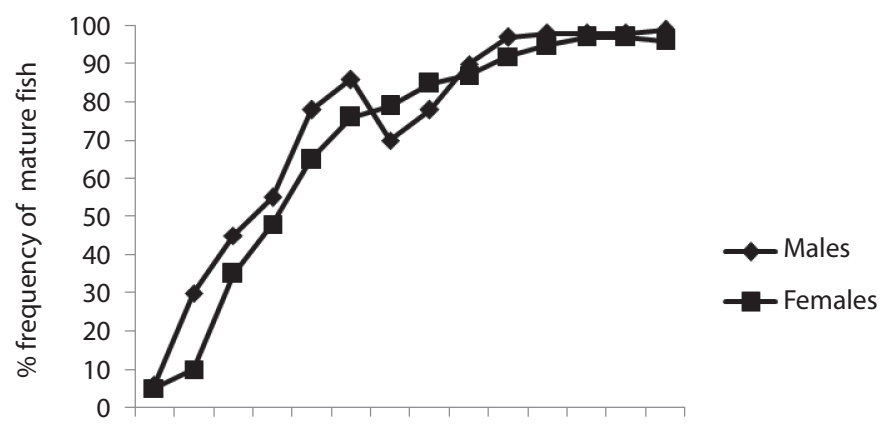

$5 \quad 10152025303540455055606570$

Total length $(\mathrm{cm})$

Fig. 1. Percentage frequency of mature male and female $C$. nigrodigitatus at different lengths.

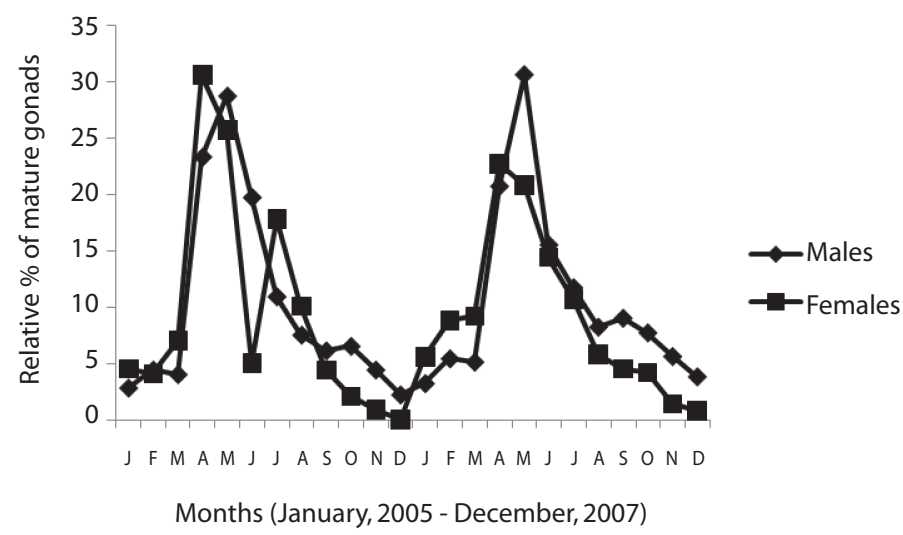

Fig. 2. Relative percentage of matured gonads in the male and female of C. anguillaris in Cross River.

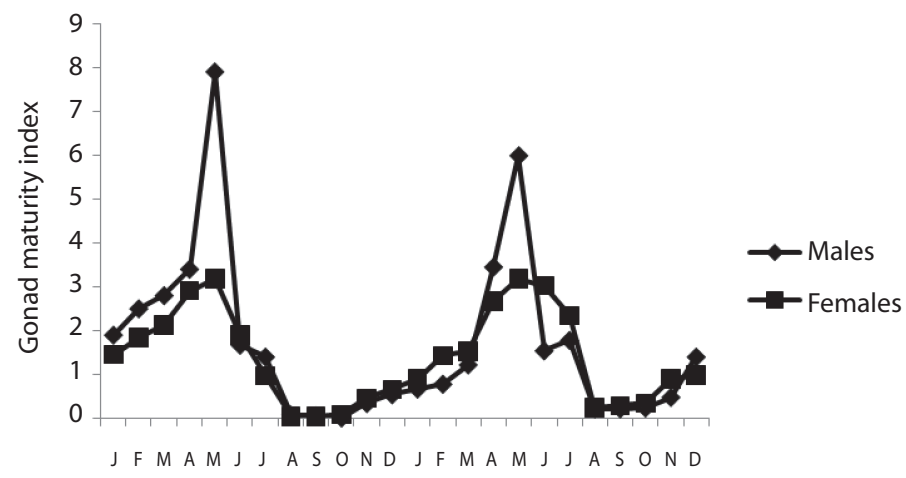

Months (January, 2005 - December, 2007)

Fig. 3. Dynamics in the gonado - somatic index (GSI) of C. nigrodigitatus male and female in Cross River. 
TABLE 1

Monthy variation in the sex ratio (male: female) of Chrysichthys nigrodigitatus in Cross River inland wetlands

\begin{tabular}{|c|c|c|c|c|c|}
\hline $\begin{array}{l}\text { Year/ } \\
\text { month }\end{array}$ & Sample & Male & Female & $\begin{array}{c}\text { Sex } \\
\text { ratio }\end{array}$ & $\begin{array}{l}\text { Chi- } \\
\text { square }\end{array}$ \\
\hline \multicolumn{6}{|l|}{2005} \\
\hline $\mathrm{J}$ & 32 & 23 & 9 & $1: .4$ & $7.00 *$ \\
\hline $\mathrm{F}$ & 28 & 17 & 11 & $1: .6$ & 3.45 \\
\hline M & 20 & 11 & 9 & $1: .6$ & $5.12 *$ \\
\hline A & 20 & 12 & 8 & $1: .5$ & 2 \\
\hline M & 78 & 55 & 23 & $1: .3$ & $29.55^{* *}$ \\
\hline $\mathrm{J}$ & 122 & 87 & 35 & $1: .6$ & $22.49 * *$ \\
\hline $\mathrm{J}$ & 106 & 65 & 42 & $1: .7$ & $10.67 * *$ \\
\hline A & 31 & 20 & 11 & $1: .3$ & $19.25^{* *}$ \\
\hline $\mathrm{S}$ & 40 & 12 & 28 & $1: .2$ & $21.41 * *$ \\
\hline $\mathrm{O}$ & 9 & 9 & 0 & 0 & $5.41 *$ \\
\hline $\mathrm{N}$ & 96 & 66 & 30 & $1: .6$ & $5.30 *$ \\
\hline $\mathrm{D}$ & 40 & 25 & 15 & $1: .6$ & $5.41 *$ \\
\hline \multicolumn{6}{|l|}{2006} \\
\hline $\mathrm{J}$ & 18 & 4 & 14 & $1: .3$ & 2.64 \\
\hline $\mathrm{F}$ & 22 & 13 & 8 & $1: .4$ & 2 \\
\hline M & 26 & 11 & 15 & $1: .7$ & 1.26 \\
\hline A & 39 & 24 & 15 & $1: .6$ & 2.14 \\
\hline M & 82 & 55 & 25 & $1: .5$ & $7.81 *$ \\
\hline $\mathrm{J}$ & 106 & 71 & 31 & $1: .3$ & $20.52 * *$ \\
\hline $\mathrm{J}$ & 110 & 77 & 33 & $1: .2$ & $15.15^{* *}$ \\
\hline A & 52 & 35 & 15 & $1: .2$ & $20.42 * *$ \\
\hline $\mathrm{S}$ & 16 & 9 & 7 & $1: .4$ & 2.92 \\
\hline $\mathrm{O}$ & 24 & 8 & 6 & $1: .3$ & 1.86 \\
\hline $\mathrm{N}$ & 66 & 44 & 22 & $1: .4$ & $8.64^{*}$ \\
\hline $\mathrm{D}$ & 71 & 53 & 18 & $1: .2$ & $14.42 * *$ \\
\hline
\end{tabular}

Significant @ *p=0.05 and ${ }^{* *} p=0.001$.

very low during August and October. It began to increase in November, and increased considerably in April. The highest value was in the month of May.

Absolute (individual) fecundity of the fish ranged from 6844 eggs [fish: $16.7 \mathrm{~cm}$ (TL); 87.8g (Body weight: BW)] to 25905 eggs [(fish: $42.4 \mathrm{~cm}(\mathrm{TL}) ; 2354.8 \mathrm{~g}(\mathrm{BW})$ ] with relative fecundity range from 342-432 eggs $\mathrm{cm}^{-1}$ to 67-82 eggs $\mathrm{gm}^{-1}$. Mean fecundity range between $4522 \pm 1924$ eggs in Zone 1 and 20321 \pm 5543 eggs in Zone III. Fecundity was high during April- June, and falls sharply during August- September and remains constant until January (Figure 4). The regression models of the relationship of fecundity with total length and body weight of the fish were $\mathrm{F}=2365.88$ $+560.22 \log \mathrm{L}\left(\mathrm{r}^{2}=0.74, \mathrm{P}<0.001\right)$ and $\mathrm{F}=$ $5025.81+56.34 \log \mathrm{W}\left(\mathrm{r}^{2}=0.71, \mathrm{P}<0.001\right)$ and are shown in Figures 5 and 6 respectively. Fecundity was directly proportional to length and weight of the fish.

The diameter of oocytes ranged from $0.2 \mathrm{~mm}-0.8 \mathrm{~mm}$ diameter and $0.30-0.60 \mathrm{mg}$ weight for immature eggs; maturing eggs ranged from $0.8-1.6 \mathrm{~mm}$ diameter and 0.70 $0.78 \mathrm{mg}$ weight while mature eggs from 1.7 $-4.7 \mathrm{~mm}$ and weight from $0.0 .82-1.88 \mathrm{mg}$. The frequency of occurrence of eggs at different diameter plotted against different months showed that immature eggs were present in the ovaries during September - February; maturing eggs during March - April and mature eggs during April - June with peak in May. The frequency of mature eggs began to drop from July while these were completely absent during September - January. This is presented in Figure 7.

\section{Length - Weight Relationship (LWR):} The 1248 specimens examined, ranged from 16.7 to $42.4 \mathrm{~cm}$ total length and $87.8 \mathrm{~g}$ to $2354.8 \mathrm{~g}$ weight. Overall pattern of lengthweight Relationship for the 3 zones gave the following exponential equations;

$\begin{aligned} \mathrm{Wt} & =-1.997 \mathrm{Lt}^{2.206} \\ \mathrm{Wt} & =-2.831 \mathrm{Lt}^{3.040} \\ \mathrm{Wt} & =-2.245 \mathrm{Lt}^{2.995}\end{aligned}$

Zone I

Zone II

Zone III

$\mathrm{Wt}=$ total weight, $\mathrm{Lt}=$ standard length.

Significant correlation exists between fish length and weight at the 3 zones. $(r=0.921$, 
TABLE 2

Individuals of female and male C. nigrodigitatus as a function of mean percentage maturity stages

$\begin{array}{lcccc}\text { Maturity stages } & \mathrm{N} & \text { Female } & \mathrm{N} & \begin{array}{c}\text { Male } \\ \%\end{array} \\ \text { IV(I) } & 2 & \% & 14 & 1.8 \pm 0.6 \\ \text { DV(II) } & 4 & 0.4 \pm 0.2 & 28 & 3.9 \pm 1.6 \\ \text { D(III) } & 1 & 0.8 \pm 0.4 & 15 & 1.9 \pm 0.7 \\ \text { MS(IV) } & 37 & 0.3 \pm 0.1 & 38 & 4.9 \pm 1.4 \\ \text { M(V) } & 143 & 8.3 \pm 2.3 & 41 & 5.2 \pm 2.6 \\ \text { R(VI) } & 60 & 22.5 \pm 6.4 & 464 & 59.5 \pm 8.6 \\ \text { S(VII) } & 229 & 12.9 \pm 4.6 & 152 & 19.5 \pm 4.3 \\ \text { RS(VIII) } & 26 & 49.4 \pm 8.9 & 27 & 3.5 \pm 0.8\end{array}$

IV(I): Immature virgin stage, DV(II): Developing virgin stage, D(III): Develop stage, MS(IV): Maturing stage), M(V): Mature stage, R(VI): Ripe stage, S(VII): Spent stage, RS(VIII): Recovering spent stage.

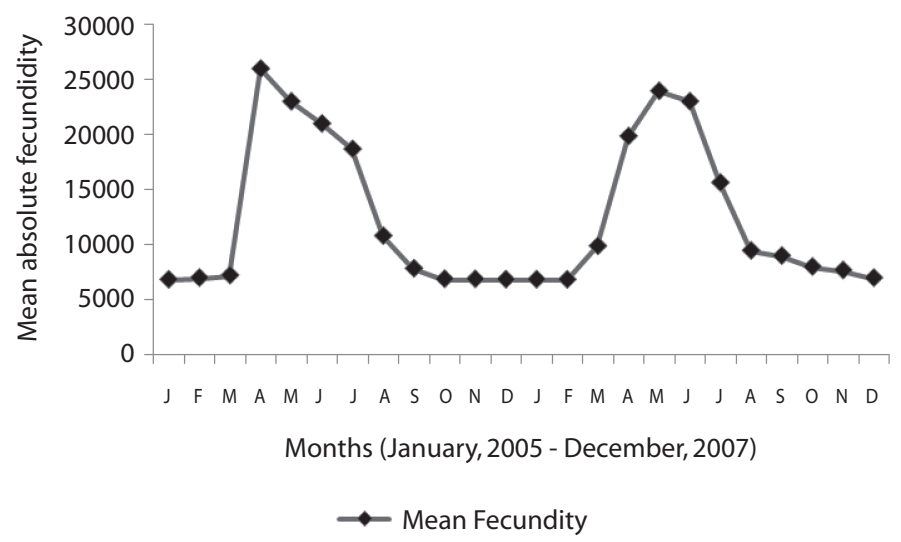

Fig. 4. Monthly variations in the mean fecundity of $C$. nigrodigitatus in Cross River.

0.883 and 0.900 for Zones I, II and III) respectively. The overall mean allometric coefficient (b) were $2.206 \pm 0.417$ (Zone I), $3.040 \pm 0.241$ (Zone II) and $2.995 \pm 0.142$ (Zone III). The b-value (2.206) for Zone I was significantly different from the cubic value $(\mathrm{P}<0.05)$ depicting negative allometry. The $\mathrm{b}$ value 3.040 for Zone II and 2.995 for Zone III were not significantly different from the cubic value $(\mathrm{P}>0.05)$.

Inter-seasonal differences in allometric coefficient were not significant $(\mathrm{P}>0.05)$.
However the peak dry season (March) and peak wet seasons (August - September) samples recorded slightly low values (Figure 8). Monthly variability was higher in Zone I $(21.2 \%)$ followed by Zone II (13.8\%) then Zone I (6.4\%).

Regression equations for male and female fish in the 3 zones are shown in Table 3. Annual proportionality constant (a) for C. nigrodigitatus in the three zones were $-1.320 \pm 0.321$ (upper river), $-2.486 \pm 0.392$ (middle river) 


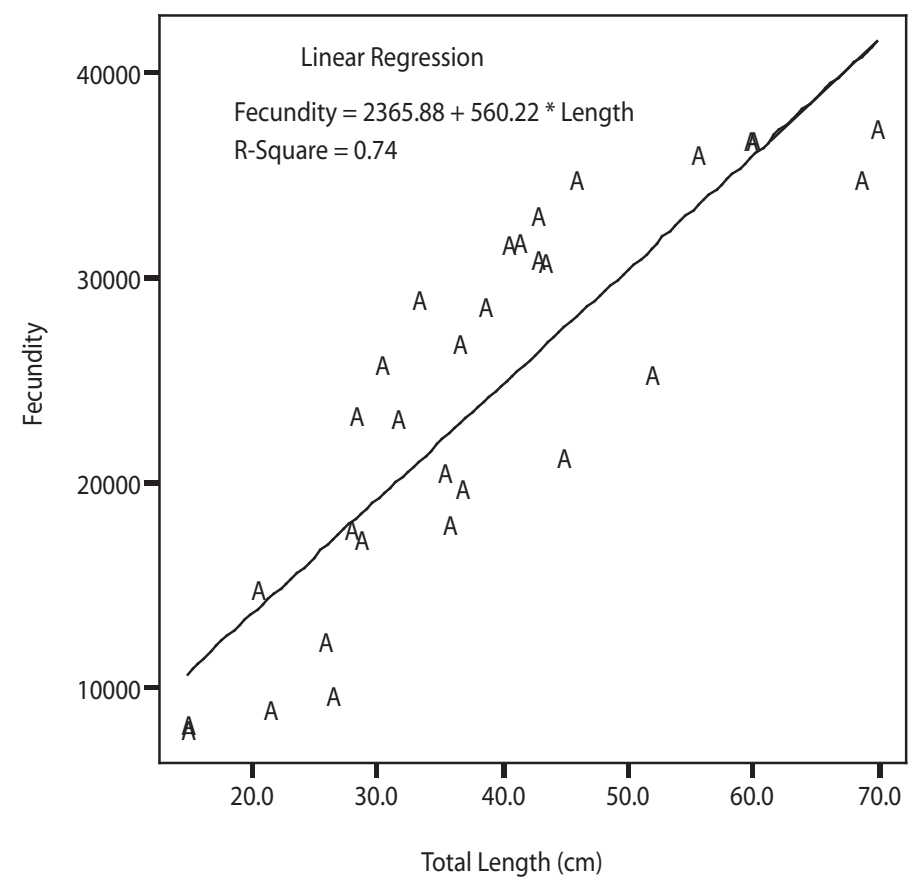

Fig. 5. Regression Curve showing relationship between Fecundity and total length of C. nigrodigitatus.

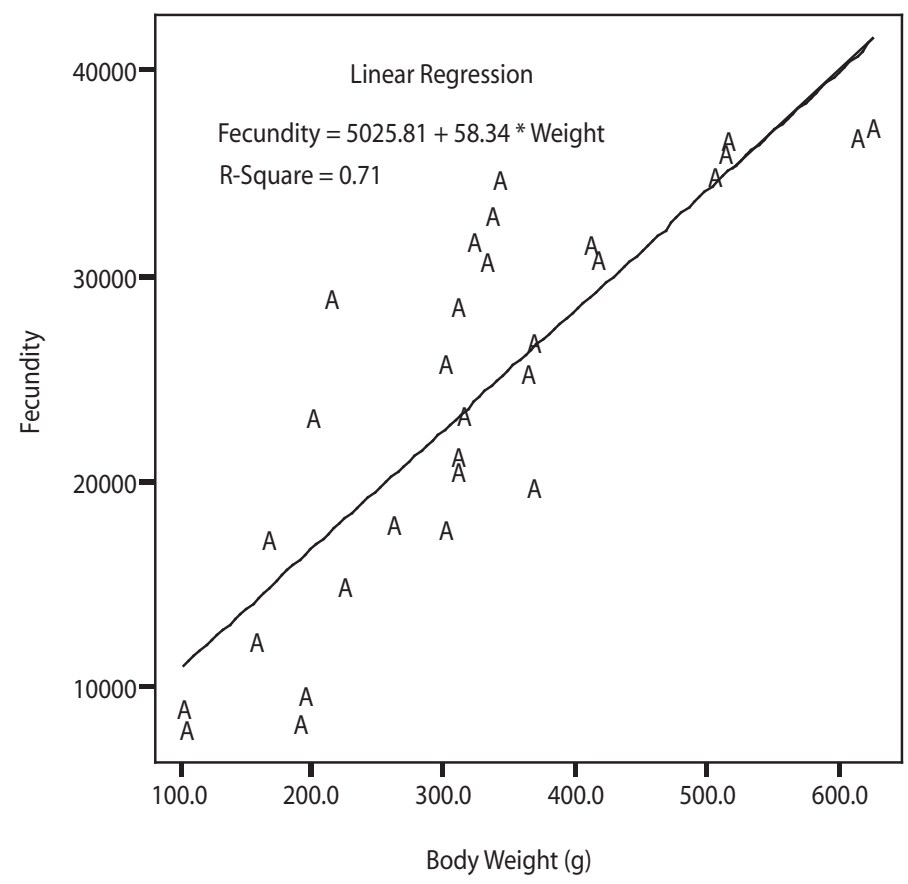

Fig. 6. Regression line showing relationship between Fecundity and Body weight of C. nigrodigitatus. 


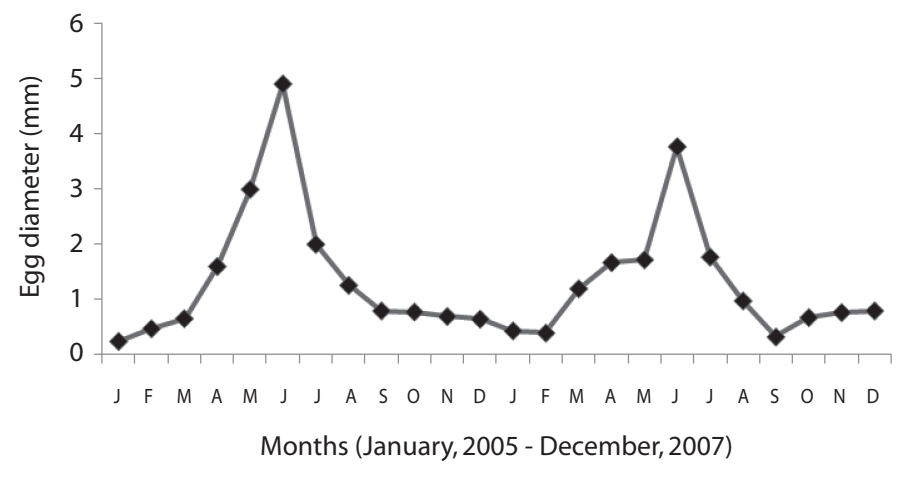

Egg diameter ( $\mathrm{mm})$

Fig. 7. Monthly variation in egg diameter of C. nigrodigitatus in Cross River.

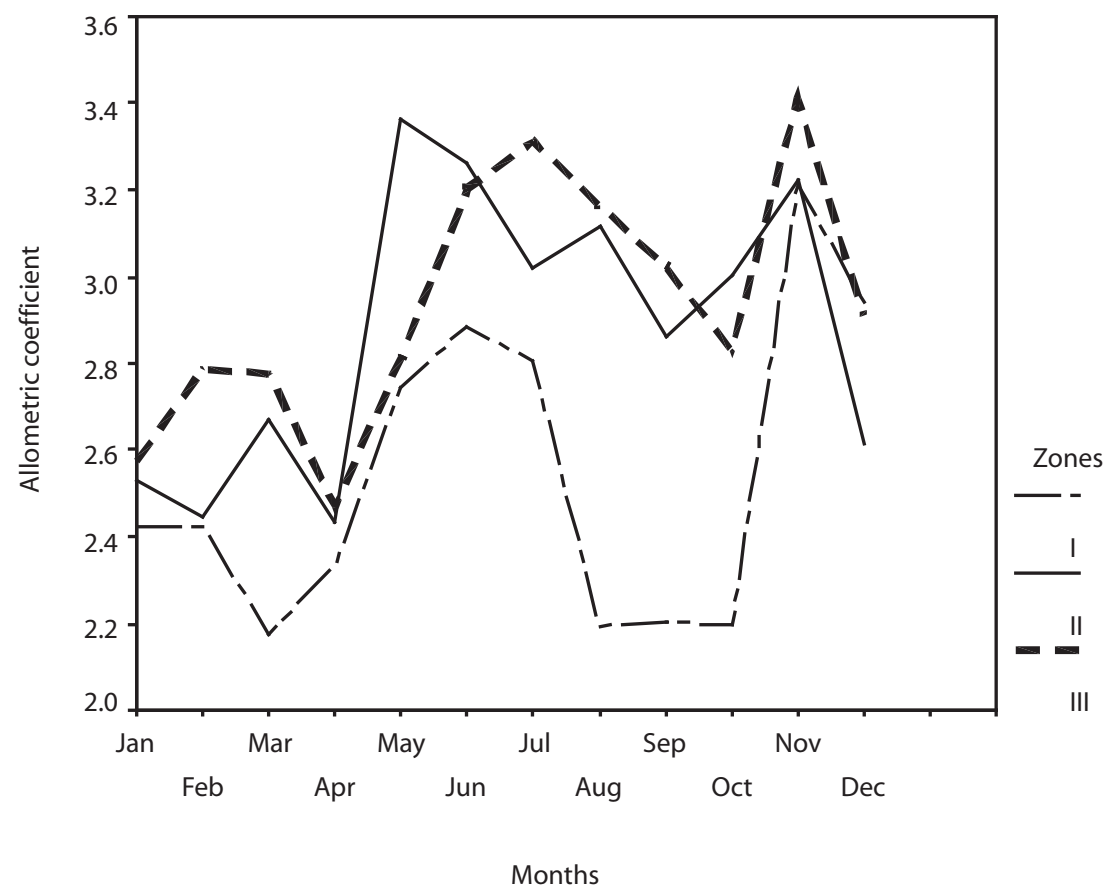

Fig. 8: Monthly mean variation in the parameters of Length - weight relationship of C. nigrodigitatus.

and $3.03 \pm 0.202$ (lower river) with significant differences $(\mathrm{p}<0.05)$ for fish samples between Upper river and the other reaches.

Condition Factor: The condition factor ranged from $0.533-1.261$ with annual mean ranged from $0.718 \pm 0.117$ minimum (males) at
Zone I to $0.996 \pm 0.062$ maximum (males) in Zone III (Figure 9). There was no significant inter-seasonal and inter-sexual variation in condition factor between specimens in Zone I, Zone II and Zone III $(\mathrm{P}>0.05)$. The highest condition factor for female $C$. nigrodigitatus was recorded between June and August while 
TABLE 3

Inter-sexual regression equations for $C$. nigrodigitatus in the three zones Wt: total body weight, Lt: total length

$$
\begin{array}{ccc}
\text { Zone } & \multicolumn{2}{c}{\text { Variables }} \\
\text { I } & \mathrm{Wt}=-1.496 \mathrm{Lt}^{2.514} & \mathrm{Wt}=-1.34 \mathrm{Lt}^{2.041} \\
\text { II } & \mathrm{Wt}=2.520 \mathrm{Lt}^{3.140} & \mathrm{Wt}=-1.964 \mathrm{Lt}^{2.841} \\
\text { III } & \mathrm{Wt}=-1.946 \mathrm{Lt}^{3.140} & \mathrm{Wt}=-2.011 \mathrm{Lt}^{2.914}
\end{array}
$$

males CF peaked between November and December.

\section{Diet habit}

Frequency of occurrence: Based on the frequency of occurrence dominant food items in the diet of $C$. nigrodigitatus was fish and fish parts $(21.6 \%)$, insects $(19.6 \%)$, crustaceans and seeds (14.4\% each). Others were mollusk $(9.7 \%)$, worms $(6.5 \%)$, algae $(4.1 \%)$, plant parts (4.1\%), detritus (3.3) and rotifers (1.5). Spatial heterogeneity was observed in the trophic attributes of Bagrid catfish with fish and fish remains constituting 25.4, 24.7 and 38.8 percent followed by insects $(6.8,26.1$ and 50.1 percent), Crustaceans (13.8, 15.6 and 28.0 percent) worms (2.4, 7.9 and 16.5), rotifers $(0.5,2.0$ and 3.3) and plant materials 11.2, 3.8 and 25.8 percent) in Zone I, II and III respectively. Therefore, major food items as shown in Table 4: Zone I were plant parts (25.4\%), Zone II: insects (26.1\%) and Zone III: fish and fish parts $(50.1 \%)$.

Percent composition of diet: A total of 87,981 food items in the 450 non-empty gut samples were identified corresponding to 18 taxa from 8 major groups. The major groups are: fish, insects, crustaceans, mollusk, worms, rotifers and plant materials, detritus. Fish species were dominant food category in terms of percent by number. Insects and crustaceans were also common dietary items. The remaining category contributed noticeably less to the diet. Indices of the diet composition revealed that Food richness 18 (all Zones), diet breath; 0.802 (Zone 1) 0.922 (Zone II) and 0.910 (Zone III) and Gut Repletion Index (GRI); 100\% (all zones).

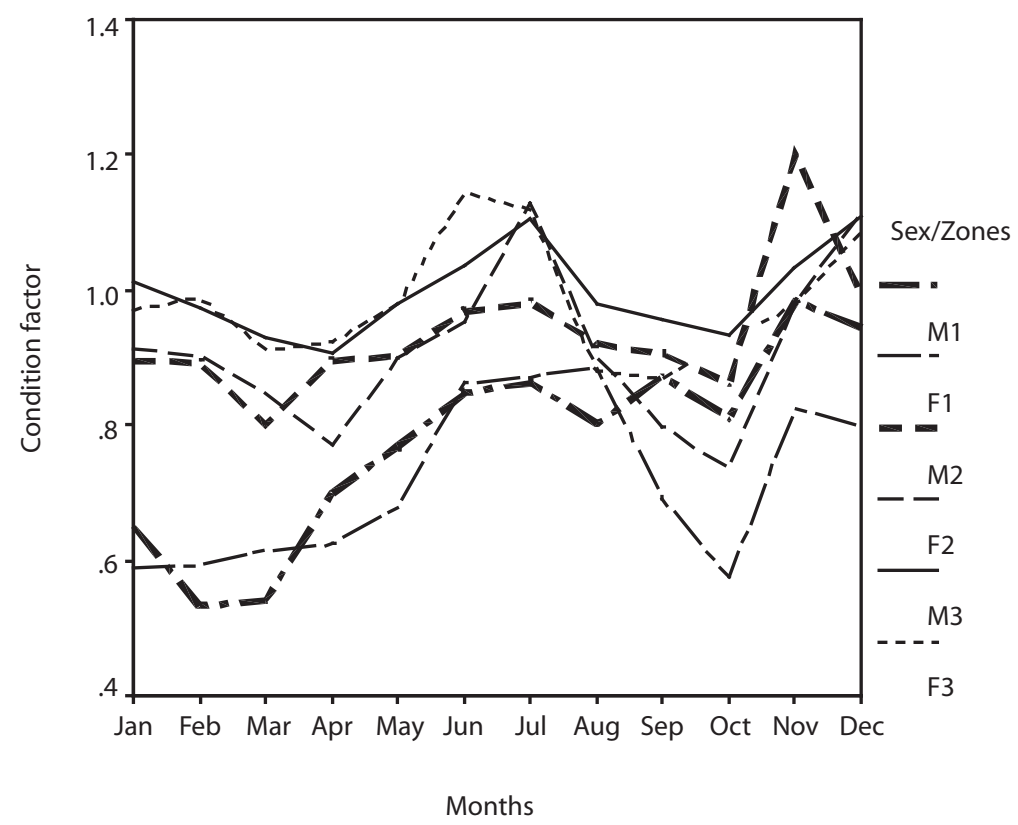

Fig. 9. Monthly mean variation of condition factor of C. nigrodigitatus (male and female) in the Cross River. 
TABLE 4

Percentage food item in the stomach of $C$. nigrodigitatus in Cross River inland wetlands FO: \% frequency of occurrence, $N$ : fish composition by number

No $=150$

Zones

Methods

Worms

$\begin{array}{lcccccc}\text { Annelids } & 1.8 & 1.2 & 6 & 5.2 & 13 & 8.2 \\ \text { Nematodes } & 0.6 & 0.4 & 1.9 & 1.1 & 3.6 & 1.8\end{array}$

Insects

$\begin{array}{lcccccc}\text { Odonata } & 1.4 & 2.2 & 8.7 & 4.7 & 4.9 & 7.2 \\ \text { Hemiptera } & 0.6 & 0.4 & 4 & 2.6 & 5.9 & 3 \\ \text { Heminoptera } & 2.2 & 1.3 & 4 & 2.6 & 20 & 8 \\ \text { Insect parts } & 2.9 & 2.3 & 13 & 8.5 & 19 & 11\end{array}$

Crustacea

\begin{tabular}{|c|c|c|c|c|c|c|}
\hline Bivalves & 2.2 & 1.7 & 2.4 & 4.6 & 8.2 & 3.7 \\
\hline Gastropods & 2.4 & 2 & 7.7 & 3.2 & 3.3 & 3.8 \\
\hline Decapods & 12 & 12 & 13 & 12 & 20 & 8.3 \\
\hline Rotifers & 0.5 & 0.3 & 2 & 1.7 & 3.3 & 2 \\
\hline Mollusks & 7.3 & 6.7 & 20 & 16 & 13 & 7.5 \\
\hline \multicolumn{7}{|l|}{ Fish } \\
\hline Adult & 1.8 & 2.2 & 3.8 & 2.6 & 3.6 & 2 \\
\hline Juveniles & 10 & 14 & 12 & 9.7 & 20 & 12 \\
\hline Fish eggs & 2.1 & 3.4 & 1.7 & 2.4 & 1.8 & 2 \\
\hline Fish parts & 11 & 11 & 6.7 & 5.5 & 13 & 7.5 \\
\hline Algae & 13 & 13 & 2.1 & 3.9 & 3.8 & 2.9 \\
\hline Seeds & 19 & 19 & 16 & 3.9 & 15 & 17 \\
\hline Plant remains & 11 & 12 & 3.8 & 3.5 & 26 & 1.2 \\
\hline Food richness & \multicolumn{2}{|c|}{18} & \multicolumn{2}{|c|}{18} & \multicolumn{2}{|c|}{18} \\
\hline Diet breadth & \multicolumn{2}{|c|}{0.8} & \multicolumn{2}{|c|}{0.92} & \multicolumn{2}{|c|}{0.91} \\
\hline Gut repletion index & \multicolumn{2}{|c|}{$100 \%$} & \multicolumn{2}{|c|}{$100 \%$} & & $0 \%$ \\
\hline
\end{tabular}

\section{DISCUSSION}

Reproductive biology: Preponderance of the male specimens over the female as observed in Cross River has similarly been observed in populations of other catfishes in some Nigerian water bodies by Abayomi and Arawomo (1996) and Taiwo and Aransiola (2001); 1: 0.15 for C. nigrodigitatus and 1:0.80 for C. walkeri in Asejire Lake. However, Imevbore and Bakare (1970) recorded lower male: female ratio for both $C$. auratus and $C$. nigrodigitatus of 1:2 and 1:4 respectively. It is important to stand out the fact that having more males than females fish species in the study area could be favourable to the fishery because it can serve as a regulatory mechanism for the sex ratio. This may be due to the fact that the gears are not set close to breeding ground. Also, Fagade and Adebisi (1979) pointed out that in African water bodies it is common that in the populations of fish the males dominate because they generally present more growth than females without this representing a risk situation for the fishery. Also the seasonal variation in the sex ratio observed was probably because once fertilization of the eggs has ended, males possibly emigrate from spawning areas towards feeding grounds located in shallow part (where they are captured). The females could go towards submerged vegetation and rocky areas to avoid the fishermen and carry out the incubation and protection of offspring. Ham (1981) attributed this disparity to differential survival over certain environmental conditions.

Males $(11.5 \mathrm{~cm})$ reached sexual maturity before females $(16.7 \mathrm{~cm})$. Knowledge of the phases of gonadal development is important for understanding the dynamics of the gonads and to assess reproductive mechanism of a species. As ovaries develop, they presented accentuated differences in size and form. The mature stage is evidenced by its largest volume. Variations in the form occurred, starting from the filiform appearance of the immature stage, becoming lobular along the maturation process, and resulting wrinkled after spawning. Afterwards they became turgid and lobule, characterizing the starting of the recovering stage. GSI has been used as indicator of the spawning period in teleosts (De laming 1972) and its use in reproductive biology has been considered more appropriate when associated with other indicators of the reproduction as macroscopic 
observations (DeMartin and Lau 1999). Peak of GSI for this species in April/May was confirmed by the largest frequency of the matured phases during this period; characterizing a single annual spawning, and synchronic ovarian development. This explained the inability of the species to sustain itself adequately in the habitat. Catfishes generally present a single annual spawning period corresponding to the warm season or associated with high water temperature (Rimmer and Merrick 1983). GSI for females was always higher than that for males probably due to heavier ripe female gonads. Absolute fecundity of 25905 eggs recorded for $C$. nigrodigitatus in this study is higher than 16300 eggs recorded for the fish in Warri Creek by Ezenwa et al (1986), 12063 eggs obtain for the same species in the Cross River estuary by Ekanem (2000), 12602 eggs recorded in Badagry Lagoon and 11316 eggs in Imo River by Ezenwa et al (1986) and 2884 eggs recorded for the species in Lake Asejire (Fagade and Adebisi 1979) depicting superiority of the Cross River inland populations over all other. The findings of Ezenwa et al (1986) on populations of this species at Badagry Lagoon, Warri River and Imo River confirmed that there are regional differences in the fecundity of $C$. nigrodigitatus as found in other fish species (Leone 1967). However, the differences between 14 eggs / $g$ relative fecundity obtained by Hem (1986) for this species in Cote 'dIvoire and 13 eggs/g obtained in Cross River estuary by Ekanem (2000) and 13 eggs/g obtained in this study indicates that the regional difference is not very pronounced. Seasonal and spatial variation in the fecundity of $C$. nigrodigitatus in this study is highly related to food. Fish with high condition factor would be expected to have higher egg production than those of low CF (Baltz and Moyle 1982). Hence the observed higher fecundity of fish in Zone III than other Zones is a manifestation of these reproductive traits. Harding (1966) stated that most tropical fishes are adopted to breed on the rising flood thus allowing the juveniles to take full advantage of the flooded banks for feeding while protected from predation. The results of the present work suggest that the relation between the absolute fecundity and the total length or weight can be formulated in both ways: as a power function or as a linear one. In both cases high determination coefficients were obtained. Demska-Zakes and Dlugosz (1995) believed that fish with such relations show faster growth rate at the same tune with higher fecundity and that the parameters to a large extent depend on environmental conditions.

The growth of eggs has a course similar to that of the entire ovaries. Occurrence of eggs of varying sizes between individuals in this study confirms data of other authors (Domagala and Trzebiatowski 1987) who have shown that older, and thus as a rule larger female produce larger eggs. The changes observed both in GSI and egg diameter, in C. nigrodigitatus are characteristic of fishes of a cyclic, single, spawning season (Koselov 1984). The breeding period of a fish will be for a definite duration if the mature eggs are sharply separated from the stock of the immature eggs (Hicklng and Rutenberg 1936). Observations in this study that ovaries carried immature (September - Febuary) and mature eggs (April - June) separated from each other by maturing eggs (March - April) indicated that the fish has a long spawning period, which extends from April to August. It is likely that the egg size ranging from $0.2 \mathrm{~mm}$ to $4.7 \mathrm{~mm}$ are the stock of the eggs to be shed and the maturing stock will mature subsequently. By August the mature eggs started declining signaling the end of breeding season. These result indicated that for any captive breeding programs gravid fishes are available in the wild during April-August. Egg diameter observed were larger compared to other catfishes. Nawar and Yoakin (1962) found egg size range of $0.8-1.25 \mathrm{~mm}$ diameter in C. auratus, Douglas (1979), encountered size range of $0.3-1.2 \mathrm{~mm}$ diameter for $C$. filamentosus eggs in Lake Kariba, South Africa. Sidthmunka (1979) encountered egg size range of 1.3-1.6mm diameter for macrocephalus in Thailand.

The status of the ovary of the fishes caught during October to January revealed that most of the ovaries were spent. These results indicated 
that the most productive fishing period for the species in the inland wetlands of Cross River was October- January. Although the length at first maturity obtained for the fish was $16.7 \mathrm{~cm}$, the minimum length recorded for specimens with spent ovaries was $23.4 \mathrm{~cm}$. Hence closed and less intense fishing during April - September, would help conservation of the natural stock of the fish, by allowing the fish to breed at least once in their lifetime.

Diet habit: Spatial changes observed in the diet of $C$. nigrodigitatus with plant materials dominating the diets in Zone I, insects and fish remains in Zone II and III respectively implied that the species could be termed an omnivore and opportunistic feeder as suggested by Warren (1993); ingesting variety depending on availability. The wide food spectrum exhibited by $C$. nigrodigitatus revealed trophic flexibility, an ecological advantage that enables a fish to switch from one food category to another in response to fluctuation in their abundance. It also enables species to utilize many different foods effectively. High proportion of non-empty stomachs showed that they could be frequent feeders. Observation of ingestion of wider array of food subjects in Zone II and III compared to Zone I portrays greater diversity of food resources and better living conditions in the 2 forest zones.

Fish size: Length - weight relations help prediction of potential yield and determination of size at capture for obtaining optimum yield, as these management parameters are directly related to weight of fish. The relation is also useful in differentiating populations as variations occur in populations of different localities. Length-weight relationship of C. nigrodigitatus showed negative allometry (2.206) in the growth pattern in Zone1. This is an indication that the population of the species in this zone had heterogenous groups with body weights varying differently with the cube of total length. On the other hand isometric growth exhibited by this same species in Zone II (3.03) and Zone III (2.995 was an indication that these Zones have homogenous groups in their populations with body weights varying indifferently with the cube of the total length. This implies that the dynamics of fish populations in the study area can be analysed using different conventional fish population dynamic models. The general trend of negative allometry exhibited by $C$. nigrodigitatus in Zone I compared to those of the same species encountered at the other 2 zones may be attributed to savanna grassland floodplain adaptations by the species. Aransiola (1989) had earlier observed negative allometric coefficients of 1.32 and 0.842 for C. nigrodigitatus at similar circumstances in Asejire Lake. Significant inter-seasonal differences $(p<0.05)$ in the allometric coefficient (b) of $C$. nigrodigitatus from Zone $\mathrm{I}$ is an indication that biological phenomenon e.g feeding and spawning have much impact on length-weight relationship in the Zone. However, the aseasonality in the length-weight parameter of the species in Zone II and III depicts little impact of biological phenomenon on breeding activity of the species in these parts of the river.

In the 3 Zones, variations in the proportionality constant (a) were higher than the exponent (b) because the values of (a) vary with environmental factors whereas (b) tends to remain unchanged during a given life phase. This observation is consistent with that of King and Udo (1998) where variability in (a) exceeded (b) in P. barbarus. Higher condition factor range recorded for male $C$. angrodigitatus $(0.533-1.261)$ in Zone III was an indication that male sex of these species were in better condition than the female sex and an evidence of greater food abundance at Zone III than others.

Condition factor: The mean condition factor of 0.996 obtained in this study for male C. nigrodigitatus is higher than $0.9673,0.9159$ and 0.7859 reported for Badagry Lagoon, Warri River and Imo River populations respectively (Ezenwa et al. 1986) and 0.977 recorded for Cross River estuary (Ekanem 2000). The fact that $62 \%$ of the samples examined had condition 
factor above the mean indicate that the majority of fish in the population of Cross River inland wetlands are in excellent condition. Following Bagenal's (1978) explanation about condition factor and habitat, $C$. nigrodigitatus population of Cross River inland water is better adapted to survive in a poorer environment than populations from other locations studied and can therefore provide excellent broodstock for aquaculture. However, the observed monthly fluctuation could be attributable to the influence of the breeding cycle (Ikomo and Sikoti 2003) and seasonal variation in the abundance of fish food.

Spatial and monthly variation in the biological characteristics of Chrysichthys nigrodigitatus in this study is an evidence of heterogeneity in habitat type in the different zones of the study area (Welcome 1985).

\section{ACKNOWLEDGMENTS}

The authors wish to acknowledge the sponsorship of the Cross River State Government throughout the duration of this study. We also appreciate the contributions and constructive criticisms from the Senior Lecturers and Professors of the Department of Aquaculture and Fisheries Management, University of Agriculture, Abeokuta, Nigeria.

\section{REFERENCES}

Alfred Ockiya, J.F. \& A.T.J. Otobo, 1990. Biological studies of Ofonitourbo Lake in the fresh water swamps of the Niger Delta, River State, Nigeria, J. Aquat. Sci. 5: $77-82$

Aransiola, M.O. 1989. Some of the biology, nutrition and reproductive physiology of African catfish; Chrysichthys nigrodigitatus (Lacepe). Ph.D. Thesis, University of Ibadan, Ibadan. Nigeria.

Baltz, O.M. \& A.T.J. Moyle. 1982. Life history characteristics of tule parch (Hysterocarpus trask) populations in contrasting environments. J. Env. Biol. 7: 227-242.

Begon, M., J.C. Harper \& C.B. Townseed. 1986. Ecology, individuals, populations \& communities International Biological programme. Blackwell Oxford, London, England.
Berg, J. 1979. Discussion of methods of investigating the food of fishes with reference to a prelimnary study of the prey of Gobiusculus flavescens (Gobiidae). Mar. Biol. 50: 263 - 273.

Borutsky, E.V., A.V. Assman, E.N. Bokova, L.A. Chayanova, K.R. Fortunatova, A.F. Karpevich, M. \& V. Zheltenkova. 1961. Handbook for the study of food and feeding of fish under natural conditions. Akademiya Nauk, Moscow, Russia.

Bruton, M.N. 1979. The breeding biology and early development of the catfish (Clarias gariepinus) in Lake Sibaya, South Africa with a review of breeding in species of the subgenius Clarias (Pisces: Claridae). J. Trans-discipl. Env. Stud. 35: 1-45.

Damagala, J. \& T. Trzebiatowski. 1987. Effect of the female size and its eggs diameter on survival and growth of a young stock of trout. Gosp Rybna 3: 8-9

DeMartini, E.E. \& B.B. Lau. 1999. Morphometric criteria for estimating sexual maturity in two snappers, Etelis carbunculus and Pristopomoides sieboldii. J. Fish. Biol. 97: 449- 458.

De Vlaming, V. L. 1972. The effect of temperature and photoperiod on reproductive cycling in the estuarine gobiid fish (Gillichthys mirabilis). Fish Bull. 73: 1137- 1157.

Demska-Zakes, K. \& M. Dlugosz. 1995. Fecundity of vendace from two lakes of Mazurian district. Rybna 31:37-50.

Dmitincko, E.M. 1970. Reproduction of the sea catfish (Arius thalassinus: Rupel) in the Arabian sea, J. Appl. Ichthyol. 10: 361-364.

Ekanem, S.B. 1992. Studies on the freshwater pond culture of Chrysichthys nigrodigitatus (Lacepede) Ph. D. Thesis University of Calabar, Osun, Nigeria.

Ekanem, S.B. 2000. Some reproductive aspects of Chrysichthys nigrodigitatus (Lacepede) from Cross River Nigeria. Naga, ICLARM (Vol. 2, No. 2).

Enin, U.I. 1994. The artisanal shrimp fishery of the Outer Cross River Estuary, Nigeria. Ph.D. Thesis, University of Calabar, Osun, Nigeria.

Ezenwa, B. 1981. A study of the reproductive biology of the catfish Chrysichthys nigrodigitatus (Lacepede) in Nigeria. University of Lagos, Lagos, Nigeria.

Ezenwa, B.L.O. 1982. Production of catfish, Chrysichthys nigrodigitatus, in brackishwater ponds in Nigera using groundnuts cake as supplemental feed. Aquaculture 27:198 - 203 . 
Ezenwa, B.L., L. Ikusemiju \& C.I.O. Olaniyan. 1986. Comparative studies of the Catfish, Chrysichthys nigrodigitatus (Lacepede) in three isolated geographical areas in Nigeria for breeding purposes, In E. A. Huisman (ed.) Aquacult. Res. in the African region. Wageningen, Gelderland, The Netherlands.

Fagade, S.O. \& A.A. Adebisi. 1979. On the Fecundity of Chrysichthys nigrodigitatus (Lacepede) of Asejire dam, Oyo State Nigeria. Nig. J. Nat. Sci. 1:127-131.

Fisher R.A. 1970. Statistical methods for research workers. $14^{\text {th }}$. Edn. Oliver and Boyd, Edinburgh, United Kingdom.

Fischer W. \& G. Bianchi 1984. FAO species identification sheets for fishery area $34,47 \mathrm{pp}$.

Ham, R. 1981. The ecology of six native and two introduced fish species in Enoggera creek system, south east, Queens land. B.Sc (Hons)Thesis. Griffith Universidad, Brisbane, Australia.

Harding, D. 1966. Lake Kariba: the hydrology and development of fisheries, p. 123-134. In R.H. Lowe Mc Connel (ed.). Man made lakes. Academic, London, England.

Hickling, C.F \& E. Rutenberg. 1936. The ovary as an indicator of spawning period in fishes. Mar. Biol. Assoc. UK 21: $311-412$.

Hynes, N.B.N. 1950. The food of freshwater stikle backs (Gesterosterus aculetus and Pygosteus pungitus) within a review of methods used in studies of the food of fishes. J. Ani. Ecol. 19: 15-36.

Imevbore, A.M.A. 1969. Hydrobiology and plankton of Eleyele Reservoir, Ibadan Nigeria. Hydrobiologia 30 (1):154-175.

June, F.C. 1953. Spawning of yellwfin tuna in Hawaiian waters. Fisheries Bulletin 54: $47-61$.

King, R.P. \& M.T. Udo. 1998. Dynamics in the lengthweight parameters of the mudskipper, Periophthalmus barbarus (Gobiidae), in Imo River estuary, Nigeria. Hagolander Meer 52: 179-186.
Koselov, B.V. 1984. Ekologia rozmnozenia ryb. Nauka, Moscow, Russia.

Lamai, S.L. 1993. Aspects of the Applied biology of Clarias gariepinus (Burchell, 1822) Aquacultural techniques and deldrin toxicity. Ph.D. University of Reading, London, United Kingdom.

Leone, C.C. 1967. Fecundity of surf smelt in the state of Washington. M.Sc. Thesis University of Washington, Washington DC, U.S.A.

Lewontin, R.C. 1966. On the measurement of relative variability system. Zoologia 15:141-142.

Nawar, G.E. \& G. Yoakin. 1962. A study on the fecundity of the nile catfish, Clarias lazera, Annuals and magazine of natural history 135: 345-365.

Olaosebikan, B.D.,and Raji, A. 1988. Field guide to Nigerian freshwater fishes. FCFF, New Bussa, Bogu, Nigeria.

Pauly, D. 1984. Fish population dynamics in tropical waters: a manual for use with programmable calculators. ICLARM Studies and Reviews. 8: 325.

Pinkas, L., M.S. Oliphant \& I.K.L. Iverson. 1971. Food habits of albacore, bluefin tuna and bonito in California waters. Calif. Dept. Fish and Game fish ULL 152: 105 .

Rimmer, M.A. \& J.R. Merrick. 1983. A review of the reproduction and development in the fork-tailed catfishes (Ariidae). J. Limnol. Soc. Lond. 107: 41-50.

Schoener, T.W. 1970. Non- synchronous spetal overlap of lizards in patchy habitat. J. Ecol. 51: 1228- 1250.

Silvalingam, S. 1972 Fish culture possibility around Lagos Logoon and the results of recent trials Fed.Fish. Occas. Pap. 13:21p.

Sidthimunka, A. 1972. The culture of Pla Duk, Clarias spp. Inland Fish. Div., Dept. of Fisheries, Bangkok. 12: 17.

Taiwo, I.O. \& M.O. Aransiola. 2001. Length - weight relationship, condition factors and fecundity of Chriysichthys nigrodigitatus and Chrysichthys walkeri in Asejire Lake. p. 227 In Abstracts Conf. FISON 2001, Lagos, Nigeria. 
Teugels, G.G., G. Mccreid \& P. King. 1992. Fishes of the Cross River Basin (Cameroon Nigeria) taxonomy, zoogeography, ecology and conservation. Musee Roya 1 de 1 Afrique Centrale, Belgium Annales Sciences Zoologiques. 266: 124.

Vanderwaals, B.C.W. 1974. Observation on the breeding habits of African catfish Clarias gariepinus (Burchell). J. Fish. Biol. 48: 6-10.

Vazzoler, A.M. \& A.M. de. 1996. Biologia reproductiva de peixes teleosteos: Teoria e pratica.Maringa,
Editora Universidad Estadual de Maringa e Sociedad Brasleira de Ictiologia,

Brasila CNPq/Programa Nacional de Zoologia. 169: 65.233 .

Warren, W.G. 1993. Changes in the within-survey spatial temporal structure of the northern cod (Gadus morhua) population, 1985-1993. Can. J. Fish. Aquat. Sci. 54 (1): 139 - 148.

Welcome, R.L. 1985. River fisheries FAO Fish Tech. Paper 262. FAO, Rome. 
